\title{
Sequestering carbon in natural forests
}

Binkley, C.S.

CRC Press

1997

Binkley, C.S. et al. 1997. Sequestering carbon in natural forests. Critical Reviews of

Environmental Science and Technology, 27: S23-S45.

http://hdl.handle.net/1975/315

Downloaded from Helda, University of Helsinki institutional repository.

This is an electronic reprint of the original article.

This reprint may differ from the original in pagination and typographic detail.

Please cite the original version. 


\title{
SEQUESTERING CARBON IN NATURAL FORESTS
}

\author{
C.S. BINKLEY, ${ }^{1}$ M. J. APPS, ${ }^{2}$ R. K. DIXON, ${ }^{3}$ P. E. KAUPPI, ${ }^{4}$ and \\ L.-O. NILSSON ${ }^{5}$ \\ 'Faculty of Forestry, The University of British Columbia, Vancouver, B.C., Canada, \\ V6T 1Z4; ${ }^{2}$ Canadian Forest Service, Edmonton, Alberta, Canada T6H 3S5; ${ }^{3}$ United \\ States Environmental Protection Agency, Washington, D.C. 20585, U.S.A.; ${ }^{4}$ Finnish \\ Forest Research Institute, Helsinki, 00170, Finland, ${ }^{5}$ Department of Ecology and \\ Environmental Research, Swedish University of Agricultural Sciences, Uppsala, 75007, \\ Sweden.
}

\begin{abstract}
Closed forests cover about 3 billion hectares, or $20 \%$ of the world's total land area (excluding Antarctica). Forest plantations comprise less than $1 \%$ of this area. Natural forests range from the intensively managed ones of Central Europe and Scandinavia to the wild boreal forests of Russia and Canada and the deep jungles and dry forests of the tropics. Numerous techniques-largely drawn from the ordinary repertoire of forest management--are available to enhance our ability of these forests to sequester and store $\mathrm{C}$. Although the costs of sequestering additional $\mathrm{C}$ in these forests may be quite low (even in comparison with intensive plantation options), increased use of natural forests for this purpose rasses a host of concerns about competing forest uses, biological risk, and the capacity to actually measure the incremental $\mathrm{C}$ sequestered. The problems of poverty, expanding populations, weak institutions, incomplete scientific knowledge, and climatic change itself will challenge the world's capacity to use natural forests as part of a $\mathrm{CO}_{2}$ control strategy.
\end{abstract}

KEY WORDS: sequestering carbon, hectares, forest plantations.

\section{INTRODUCTION}

Forests serve humans in many ways. Indeed, some believe that forests have intrinsic values or even rights beyond those conferred by human use alone. This paper focuses on one of these uses: The capacity of natural forests to sequester $\mathrm{CO}_{2}$ and store $\mathrm{C}$ emitted as a waste product of our industrial activities. This paper specifically discusses the mechanisms behind such $\mathrm{C}$ uptake and storage activities and the key points related to estimating the costs of accumulating $\mathrm{C}$ in natural forests. Most of these techniques are classical methods of forest management, albeit developed to achieve different objectives. While precise quantification of both the physical and economic amounts involved is possible in specific instances, it is beyond the scope of this paper. Instead, we provide a road map so the reader may pursue these important details independently. Dixon (this volume), Sedjo et al. (1995), Hoen and Solberg (1994 and this volume) and Richards and Stokes (1995) critically review some of the alternatives discussed in this paper and quantify some of the biophysical impacts and economic costs.

$1064-3389 / 97 / \$ .50$

(C) 1997 by CRC Press LLC 


\subsection{Definition of "Natural Forest"}

For the purposes of this discussion the term "natural forests" refers to those lands currently occupied by closed forests or being regenerated to the same or similar species as removed from the site after logging. We specifically exclude agricultural and other non-forested lands which are planted to tree species. We do however, consider those cases where open areas become forested through the ordinary processes of forest succession (e.g., occupation of abandoned farm lands or lands laid bare by recent glaciation). We exclude non-forested peat lands, open woodlands and savannas. This definition probably encompasses virtually all of the world's forests (Dixon et al. 1994).

Human intervention in the development of natural forests ranges from intensive culture approximating the care lavished on agricultural crops to complete diffidence. Managed forests form one end of the spectrum and wild forests the other. Examples of the former include the industrial and multiple-use forests of Scandinavia and Central Europe; examples of the latter include the remote boreal wildernesses in Canada and Russia, and the highly diverse, inaccessible tropical jungles in Brazil and Zaire. Many parks and reserves lie towards the latter end of the spectrum, but require management intervention even if it is not for the purposes of producing industrial products. All of these landscapes share the quality that the species composition of the forest overstory has been largely determined by nature.

Globally, closed natural forests cover approximately 3 billion ha of the world's land (Sharma, 1992). Forty-three percent of the natural forests are found at low latitudes, 32\% at the high latitudes and 25\% at mid-latitudes (Dixon et al. 1994a). Low-latitude forests are currently shrinking at a rate of approximately 15 million ha annually, and thereby are a source of $1.6 \mathrm{Pg}$ of $\mathrm{C}$ per year. Brazil, Indonesia, and Zaire are large $\mathrm{CO}_{2}$ sources. If tropical deforestation and land-use change were slowed or eliminated, these forests would become a large sink of $\mathrm{CO}_{2}$ (Brown et al. 1993). At present mid- and high-latitude natural forests sequester over 0.6 Pg C annually (Dixon et al. 1994a). Canada, Russia, USA, China, and the USA all have large natural forest $\mathrm{CO}_{2}$ sinks.

\subsection{How Do Natural Forests Sequester Carbon?}

All natural forests store $C$ in phytomass, forest floor litter and soils (Cole, 1995). Phytomass includes all above and below ground components of the dominant overstory tree species as well as all other vegetation comprising the overstory, understory, and forest floor cover (including lichens and mosses). In natural forests - particularly those at the wild end of the spectrum-the noncommercial components of the forest may represent a significant and even dominant component of the standing biomass. The forest floor ranges from a dominant pool in many northern forests to a negligible one in parts of the tropics (Brown, 1991). These facts make it extremely difficult to estimate $C$ stocks from commercial inventories which-when they are available-often record only the merchantable bole volumes of the economic species. The lack of accurate allometric relationships to estimate root, branch and foliage biomass from stem measurements exacerbates the problem. The non-merchantable biomass components are important not only for their contribution to total biomass, but also in their role as inputs to the other $\mathrm{C}$ pools in the ecosystem. 
Several factors distinguish $\mathrm{C}$ sequestration in natural forests from that in plantations, although the distinctions are not absolute. In natural forest systems where extensive forestry management is practiced, the fraction of Net Primary Production (NPP) that enters the forest floor as litter, dead snags or as dead-root turnover in the below-ground system is generally much higher than it is in plantation forests. Indeed, capturing this mortality as merchantable volume is one of the major objectives of plantation management. In this respect. the managed natural forests of Europe tend to resemble plantations, and the distinction between plantation and natural forests becomes very murky.

Life-cycle dynamics also distinguish natural forests and plantations. Plantation management usually seeks a 'normal' forest agc-class distribution with an equal area in each age class up to the planned rotation age. Each cohort is harvested as it reaches the rotation age and is replaced with a new cohort which then becomes the youngest age class. Management of natural forests generally includes more chaotic, stochastic processes of mortality, disturbance and succession. Storing $\mathrm{C}$ in forests by increasing the standing above-ground biomass may increase the risk of devastating disturbances associated with fire, insects or diseases. Nonetheless, a $\mathrm{C}$ benefit still accrues because the increase in atmospheric concentrations of $\mathrm{CO}_{2}$ is delayed.

The response and feedbacks of boreal, temperate and tropical forest systems to global climate change may be profound (Dixon et al. 1994b; Smith et al. 1991). Scenarios developed by coupling General Circulation Models (GCMs) of global climate with vegetation response models generally imply large shifts in the distribution and productivity of forest systems (Smith et al. 1991; Kaupp1 and Posch, 1988; (Songhen and Mendelsohn, this volume; Perez et all, this volume). Uncertainty regarding the potential redistribution of forest systems in response to global climate change complicates our ability to predict future $\mathrm{CO}_{2}$ sequestration by natural forest systems (King 1993). Even if the GCMs are only partially correct, the productivity of existing natural forests will inevitably be affected, and the current $C$ biogeochemistry, both pools and fluxes. will aiso change (Dixon et al. 1994a).

For the purposes of understanding the interaction between the $\mathrm{C}$ pools in the atmosphere, Net Ecosystem Productivity (NEP) may be a more useful concept than NPP. NEP refers to the net change in soil, litter and phytomass. Because different biogeochemical processes control each of these pools, it is possible for increases in phytomass to be negligible but for continued sequestration to occur in soil and litter pools. Such conditions may obtain in cool. moist micro-climatic conditions below the canopies of old-growth remperate forests where gap-phase replacement operates and stand-replacing disturbances are rare events (Harmon et al., 1990). In boreal forests, break-up of the overstory may be accompanied by a decrease in both the standing phytomass-and because of increased exposure and soil warmth-decreased forest floor and soil $\mathrm{C}$.

Peat is formed in natural forests in waterlogged conditions. Trees can survive on large areas at least in the carly phases of paludification (the peatland formation process). Such specialized peatland plants as Sphaghum mosses transfer organic material released from the overstory into the peat layer. Peatland forests differ from other natural forests because $\mathrm{CO}_{2}$ fixation excecds $\mathrm{CO}_{2}$ release over time frames stretching from centuries to millennia. The boreal and subarctic peatlands comprise a $\mathrm{C}$ pool estimated at $455 \mathrm{Pg}$ that has accumulated during the post-glacial period at an average net rate of $96 \mathrm{Tg} / \mathrm{yr}$ (Gorham, 1991). While this is insignificant in an overall global $\mathrm{C}$ budget where the flux from fossil-fuel combustion is at least two orders of magnitude greater, the relative contribution of peatlands to national $\mathrm{C}$ budgets is significant in some northern countries. 


\subsection{Sequestering $C$ in the Economic System}

Management of natural forests may require the removal of trees, either as a planned component of a larger industrial activity, or as a means of sustaining specific ecosystem conditions in a park or forest reserve. Such removals ordinarily enter the economic system. While the total amount of $\mathrm{C}$ fixed in forest products pools globally is less than $20 \mathrm{Pg}$ over the last 50 years (Dixon, 1994a), it may be critical in the $\mathrm{C}$ budgets of those countries where forest products production is high and consumption is low (e.g., Finland, Sweden and Canada). This paper explicitly treats the impact of removing the iree from the forest, but excludes the impacts of that material on other parts of the economic system. This procedure obviously ignores the potential role of forests to substitute for fossil fuels in the energy production, or to substitute for such energy-intensive materiais as concrete or steel in construction applications. Such calculations are beyond the scope of our analysis but are extensively treated elsewhere (e.g., Marland, this volume; Matthews, 1995).

In considering forest $\mathrm{C}$ sequestration, it is important to note that an effective option might be to optimize the capacity of forests to remove $\mathrm{CO}_{2}$ from the atmosphere but to store the $\mathrm{C}$ in forms other than plant phytomass (i.e., as a substitute for fossil fuels. or in longlived forest products). Such a strategy would involve harvesting forests at a comparatively young age, and resulting in a lower standing inventory of timber than would occur if the forests themselves were used to sequester C (Harmon et al., 1990). We discuss the impact of such strategies on the forests themselves, but do not expand this analysis to include the impact on $\mathrm{C}$ offset in the energy system or other economic activities.

\subsection{Other Policies Affect $C$ Sequestration in Natural Forests}

Policies in spheres of public affairs other than forestry frequently have a profound impact on forests. For example, agricultural subsidies have long encouraged clearing of forested land in many countries-both developed and developing. Such land-use conversion release a pulse of $\mathrm{C}$ into the atmosphere, and may also reduce the annual rate of $\mathrm{C}$ sequestration. As another example, in Scandinavia and in parts of eastern North America it is well understood that $\mathrm{N}$ deposition associated with high levels of industrial air pollution fertilizes forests, increases forest growth, and induces a higher level of $\mathrm{C}$ sequestration (Eriksson and Johansson, 1993; Nilsson and Wiklund, 1992). As a third example, international agreements on the conservation of biological diversity may require countries to sustain conditions in forested ecosystems which do not optimize their capacity to sequester C (Victor and Salt, 1995). Policy makers in these areas, seemingly remote from forests, should consider such impacts on forests (Sharma, 1992).

\section{CATALOG OF TECHNIQUES: TWELVE WAYS TO SEQUESTER CARBON}

The remainder of this paper catalogs various techniques for sequestering $\mathrm{C}$ in natural forests. The first section below describes twelve possibilities which we believe collectively cover the range of alternatives. In each case we describe the biophysical response mecha- 
nism and the possible impact on $\mathrm{C}$ sequestration. The next section covers the problems of determining the economic cost of each practice. In dealing with both the biophysical responses and the economic costs, the discussion focuses on the appropriate conceptual approach for evaluating the technique with references to specific examples on the technique reporied in the literature.

\subsection{Biophysical Responses}

We are specifically interested in the total stock of $\mathrm{C}$ held in natural forests at any point in time. Annual accumulation of $\mathrm{C}$ can be measured either as the change in $\mathrm{C}$ stocks from one year to the next, or as the sum of the changes in the stocks of the individual components of the ecosystem. In considering the different forest management techniques in different locales, one or the other method may be the more straightforward to apply, but they are conceptually identical. The total amount of $\mathrm{C}$ sequestered in natural forests simply equals the storage per hectare multiplied by the forested area. Sequestration strategies logically focus both on increasing the storage per hectare and on increasing the forested area over what it would otherwise be (Winjum et al., 1993).

\subsubsection{Protect Against Fires}

Fires, of both natural and anthropogenic origin, play an important role in the life cycle of many natural forests. From the point of view of $\mathrm{C}$ storage, fires may be broadly categorized into two types: non-stand-replacing and stand-replacing. The first are commonly associated with low-intensity but relatively frequent ground fires, and relatively open woodland structures. They often result in uneven-aged forests. Some high-latitude forest species (e.g. Pinus ponderosa) are well adapted to this fire regime but most low-latitude species are not. Such fires produce relatively low immediate $\mathrm{C}$ releases, and-by clearing understory debris-may both cleanse the forest floor of pathogens and remobilize nutrient for overstory utilization, thereby increasing subsequent $\mathrm{C}$ uptake. As a result, managers of some forests types prescribe fires as a regular practice. When fine fuels on the forest floor build to high enough levels, however, crown fires can be sustained, and stand-replacing fires may occur with very different consequences.

Stand-replacing fires are dramatic events having locally catastrophic effects leading to complete mortality of the overstory. Large, intense conflagrations are the dominant type of fire in many boreal systems (Apps and Kurz, 1993). As an example, in 1989, more than six million ha of boreal forest (an area 50\% larger than Switzerland) burned in Northern Saskatchewan in a single fire season. The Great Black Dragon Fire in Northern China and the Russian Far East covered more than 10 million ha, and the resulting smoke plume was easily seen in satcllite images extending far to the East for many days (Salisbury, 1987; Stocks, 1991). A large fire burned in Borneo in 1993 for many weeks before it was finally detected from satellite telemetry.

The effects of these fires are threefold: (i) $\mathrm{C}$ is redistributed amongst the various ecosystem pools, (ii) $\mathrm{C}$ is released to the atmosphere as $\mathrm{CO}_{2}$ and other $\mathrm{C}$ compounds including $\mathrm{CO}$ and $\mathrm{CH} 4$ (Levine, 1991 ; Crutzen and Goldammer, 1993), and (iii) the forest 
structure is changed as the stand age is 'reset' and seral succession is restarted. While such fires entail major and immediate $\mathrm{C}$ released to the atmosphere (Cofer et al., 1991; Levine, 1991) the forests where such fires occur naturally are adapted to them and, indeed, are dependent on them for regeneration, removal of pests and disease vectors, and a host of other ecological relationships.

The $\mathrm{C}$ releases associated with fire go beyond the immediate pulse to include subsequent emissions from the non-combusted, decomposing, dead biomass left on site. For example, Auclair and Carter (1993) estimate that post-fire releases may be as high as three times the immediate release. Some of this material becomes coarse woody debris (Harmon et al., 1986), or other forest floor reservoirs (Apps and Kurz, 1993; Dixon and Krankina, 1993).

While eliminating these large $\mathrm{C}$ releases is a potentially attractive option, suppression of fire may also merely open the way for other pathological agents which would normally have been kept at negligible levels by the periodic cleansing action of wild fire. For example. in Alaska the increased incidence of bark beetle and other insects has been associated with the increased frequency of overmature forests (Dixon and Krankina, 1993). The large fires in the American West during the last decade suggest that the thorough suppression of fire may be counter-productive because it results in a build-up of fine fuels and the eventual, inevitable, occurrence of a much higher intensity fire. The resulting fires have significantly greater damage to site fertility due to changes in soil structure and organic and nutrient capital than would have otherwise occurred with a series of smaller, more frequent fires.

Although fires do periodically devastate low-latitude in some regions (e.g., in Indonesia), in most moist tropical forests neither fucl loading nor fuel condition are conducive to large or intense fires. Fires may play a role in these forests in unusually dry weather patterns or after large-scale mortality caused by agents such as hurricanes or typhoons. Anthropogenic fires occur throughout low-latitude forests, as forest burning is a common management tool for resource-poor farmers. Although the size of these controlled fires is relatively small, their large number produce a globally significant pulse of greenhouse gases (Crutzen and Goldammer, 1993). During peak burning season in some low latitude countries such as Brazil, satellite sensors detect many thousands of small fires on any given day.

\subsubsection{Protecting Against Disease, Pest Insects, and Other Herbivores}

As with fire, these types of forest disturbance can be either stand replacing or endemic. Stand replacing events have the same three characteristics as stand-replacing fires, except that direct releases of $\mathrm{C}$ to the atmosphere is generally smaller (it occurs as respiration of the pathogens rather than as combustion products), and the transfer of $\mathrm{C}$ to the forest floor correspondingly greater. Protection against these sorts of events is, like fire, problematic. For example, insect-induced stand mortality depends on present year weather conditions, previous year's insect populations and (of some insects) stand-age, type and health status (Volney, 1995; Galinsky and Witrowski, 1995). Avoidance of conditions which are conducive to these disturbances is the best protection. Acrial applications of chemical or biological pesticides are generally effective in sustaining forests in a living condition long 
enough to harvest wood, but are generally not effective in eliminating insect populations altogether.

Endemic impacts of insect, disease and herbivores, may result in direct reduction of NPP by reducing the ner increment of forest phytomass. The effect on NEP and $C$ sequestration is not clear and depends on many factors. including forest age and distuxbance type (Kurz et al., 1995). In relatively mature stands, phytomass decrements associated with the endemic disturbances largely reappear as increased $\mathrm{C}$ on the forest floor and soils. In these cases the net $\mathrm{C}$ balance is determined by the relative rate of biomass replacement and forest floor decomposition. The type of litter created is also a factor. (For example, dead roots, snags and other coarse woody debris associated with individual tree mortality have longer turnover times in the cooler sheltered micro-climatic conditions below a fully developed crown than does leaf and branch litter fall following attacks of defoliators). In younger, regenerating stands, the effect of herbivory in particular may cause a regeneration delay which has a remporary, and small, impact on C storage, but may have important economic repercussions. Some level of endemic insect, disease, and/or herbivory disturbance affects all forests. The fraction of NPP consumed by these agents has not, to our knowledge, been estımared except in a few specific insiances.

Laboratory studies have demonstrated that insect herbivory of plants grown in high $\mathrm{CO}_{2}$ environments is dramatically increased (Drake 1992). As the proportion of $\mathrm{N}$ declines relative to $\mathrm{C}$ in plants grown in high $\mathrm{CO}_{2}$ conditions, insects and other grazers increase their consumption to compensate for the loss of protein. In the future, management of naturai forests as $\mathrm{CO}_{2}$ sinks will need to be adjusted to compensate for this increase in defoliation. If insects and other forest pests adapt a more aggressive consumption pattern in a future global climate, net $\mathrm{CO}_{2}$ sequestration of future forests may be less than it is in current conditions (Dixon et al. 1995).

\subsubsection{Salvage Dead and Dying Trees}

Natural disturbances leave dead or dying trees that have both positive aspects (e.g., animal habitat, landscape diversity) and negative ones (e.g., increased fuel loadings, loss of valuable timber, reduced NPP). In some cases, where both the infrastructure and the markets exist, it is possibic to salvage some or all of this dead or dying timber to recover valuable wood, reduce the risk of subsequent contagious disturbance by insects, fire or pathogens associated with the accumulation of logging debris, and rehabilitate the site for subsequent regeneration.

By moving decomposing $\mathrm{C}$ from the natural system to the economic system, it may be possible to increase the net $\mathrm{C}$ storage associated with the given piece of land. The extent to which there is a net $\mathrm{C}$ benefit in salvage operations depends on several factors. First, is the turnover rate of $\mathrm{C}$ transferred to forest products (including all process wastes) greater than the $\mathrm{C}$ turnover rate on site (Hendrikson, 1990)? Second, to what extent is site regrowth increased relative to the untreated condition? Third, how much fossil fuel is used in the salvage and product manufacture and distribution operations?

Natural disturbances may affect very large areas. There are however two significant barriers to salvage operations: operability and marketability. Lack of railroads, highways and waterways limit the access to many natural forests. Hazardous conditions that often 
exist after larger scale disturbances also restrict salvage operations. Saivaged timber has limited uses. For example, pulp and paper mills are understandably reluctant to accept wood charred by fires. Concern for inadvertent importation of insect and disease greatly restricts the markets for timber salvaged from outbreaks of these pathogens. Bioenergy might be a potentially viable market opportunity, but access and infrastructure would appear to restrict this use to highly specific instances.

\subsubsection{Change Rotations}

Cooper (1983) demonstrated that converting a forest region of fully stocked mature stands into a maximum sustained yield forest decreases the standing stock by about two thirds, and thus releases $\mathrm{CO}_{2}$ into the atmosphere. Harmon et al. (1990) simulated conversion of oldgrowth forests into young fast-growing forests and concluded that on-site $\mathrm{C}$ storage does not approach old-growth capacity for at least 200 years. They estimated that the conversion of five million hectares of old-growth forests to younger plantations in western Oregon and Washington in the last 100 years has added 1.5-1.8 Pg C into the atmosphere.

Natural forests in disturbance-dominated systems include immature as well as mature stands. Therefore, logging in natural forests does not always result in such a dramatic decrease of C pool as Harmon et al. (1990) demonstrated for the US Pacific Northwest. In some cases logging can merely substitute the natural disturbances as the mechanism by which $\mathrm{CO}_{2}$ is released into the atmosphere. In the Nordic countries, for example, the pool of $\mathrm{C}$ in forest vegetation has increased this century despite continuous and steadily increasing logging (e.g. Kauppi et al. 1995). In contrast, logging of tropical forests in Peninsular Malaysia has resulted in a dramatic reduction in $C$ storage over the past 30 years (Brown, 1991).

In a steady-state system according to Dewar's (1990) model, a very long rotation can promote $\mathrm{C}$ sequestration, if the products decay quickly. But a short rotation can also serve the same purpose given high biomass yicld, and a long product life-time and/or effective replacement of the consumption of fossil fuels. Most short rotations systems are "plantations" (and therefore beyond the scope of this paper), yet some coppice systems can be classified as "natura! forest".

Dewar (1990) formulated a model that describes $\mathrm{C}$ storage in a forest and its timber products as function of the forest growth curve. the rotation period and the $\mathrm{C}$ retention curves in timber products. He showed that, when the forest is managed for a maximum yield of biomass, the contribution of asymptotic $\mathrm{C}$ storage from timber products is about $2.5 \mathrm{D} / \mathrm{T}^{*}$ times the contribution from living trees, where $\mathrm{D}$ is the characteristic decay time for conversion of timber products to $\mathrm{C}$ dioxide, and $\mathrm{T}^{*}$ is the normal rotation period for maximum yield. When $\mathrm{D} / \mathrm{T}^{*}<1$, as the rotation period is increased indefinitely, the asymptotic level of $\mathrm{C}$ storage increases monotonically toward the value of $\mathrm{C}$ content of living trees at maturity. But when $\mathrm{D} / \mathrm{T}^{*}>1$ there is a finite, optımal rotation period, greater than $T^{*}$, for which asymptotic $\mathrm{C}$ storage is greater than the $\mathrm{C}$ content of trees at maturity.

Either lengthening or shortening the rotation age will increase the $\mathrm{C}$ stocks, depending on the initial conditions (e.g. age structure) of the forest, harvesting methods, silviculture and, in particular, the fate of harvested C (Schlamadinger and Marland, 1995; Marland and Schlamadinger, this volume). In some cases, making long-lived products from wood grown 
in short-rotation forests can sequester $\mathrm{C}$ effectively. Short-rotation management of woody crops for production of bioenergy fuel stocks, can replace or offset the need for fossil fuels (Sampson et al., 1993)

Although a careful analysis is needed for each specific case, as a rule of thumb that prolonging rotations in natural forests will generally contribute to $\mathrm{C}$ sequestration. Converting natural forests to short rotation systems can make positive sequestration contributions mainly in the longer term, that is, in the period beyond 20 to 50 years from now.

\subsubsection{Control Stand Density}

Thinning is widely used to alter the size of individual stems in a stand, the timing of their availability, and the overall amount of merchantable timber available. In some regions, stands are thinned three to five times during the rotation in order to collect material which otherwise would decay in the forest. When thinnings provide sufficient space, the remaining trees grow to larger dimensions more quickly and thus more valuable per cubic meter harvested. The trend of decreasing thinnings and an increasing share of final cuttings has prevailed in Europe since the 1970 s because logging costs are higher in thinnings than in clear cutting.

Thinning affects $\mathrm{C}$ sequestration and storage in several ways. Low thinnings utilize small stems which would otherwise decay and release $\mathrm{C}$ back to the atmosphere. High thinnings which reduce overall forest growth rates may also help sequester $\mathrm{C}$ by providing more of the total volume in longer-lived solid wood products such as lumber. Thinning-towaste will generally be neutral or negative in terms of carbon sequestration.

\subsubsection{Enhance Available Nutrients}

Water and nutrient availability control forest growth in most parts of the world (Nambiar and Sands, 1993). As a result, fertilization and irrigation will generally enhance forest NPP. For example, in Portugal and Brazil experimental Eucalyptus plots have reached annual production of up to $40 \mathrm{Mg} / \mathrm{ha} / \mathrm{yr}$ (Campinhos, 1991). In tropical Australia, Fife and Nambiar (1995) found clear responses of $\mathrm{N}$ fertilization on the growth (up to $99 \%$ growth increase) of Pinus radiata grown in a very dry environment. The authors also concluded that improved $\mathrm{N}$ status of the trees leads to more efficient water utilization. In Sweden a series of fertilization experiments have shown clear growth response due to $\mathrm{N}$ fertilization on both Pinus and Picea abies (Tamm 1992; Linder, 1995). In the most polluted parts of south west Sweden biomass production in Picea abies was doubled due to liquid fertilization with irrigation in 30 year old Picea abies (Nilsson L.O; this volume). Davey (1990) and Weetman et al. (1987) cite evidence for positive growth responses due to fertilization in both the US and Canada. Cole (1995) and Henry et al. (1994) showed a sustainable increase in basal area of 4-5 times after application of nutrient rich sewage sludge in a 45 year old Douglas fir forest. Allen (1995) has noted similar growth responses with liquid fertilization and irrigation. Fertilization may also increase $\mathrm{C}$ storage in the soil (Berdén 1994, Nilsson 1995). 
In most cases $\mathrm{N}$ is the major nutrient element explaining the production increase. However, other nutrients-mostly $\mathrm{P}, \mathrm{K}, \mathrm{Mg}$ and such micronutrients as $\mathrm{B}, \mathrm{Cu}, \mathrm{Mn}$ or $\mathrm{Zn}$ limit NPP in some areas. For example, in New Zealand, soil fertilization with P, B or Zn dramatically increases the productivity of Pinus radiata and various Eucalyptus species plantations (Nambiar and Sands, 1993). Similar vigorous responses to forest fertilization are observed in Africa and Southeast Asia in stands of Tectona, Shorea and Leucaena (Dixon el al. 1994b).

\subsubsection{Control the Water Table}

About 11.5 million hectares of borcal peat lands have been drained in the world in order to lower the water table and thereby promote forest growth (Gorham 1991). Almost all of this area can be classified as "natural forests" given the definition used in this paper. Although drainage of forested peatlands promotes forest biomass growth, but the net $\mathrm{C}$ benefit is partly offset by increased respiration in the exposed peat and (Zoltai and Martikainen, 1995). Undrained northern peat lands annually remove $76 \mathrm{Tg} \mathrm{C}$ from the aimosphere, where as the drained peat lands release $8.5 \mathrm{Tg} \mathrm{C}$ annually (Gorham 1991). Zoltai and Martikainen (1995) find that lowering water tables by $20-30 \mathrm{~cm}$ increases $\mathrm{CO}_{2}$ emissions by $150-200 \%$. They also point out that a more important, but difficult to predict, consequence of altering the water table is a change in methane $\left(\mathrm{CH}_{4}\right)$ production, an even more potent greenhouse gas than $\mathrm{CO}_{2}$.

Irrigating dry forests would have a positive impact on $\mathrm{C}$ sequestration, by increasing storage in all of the subsystems-soil, vegetation, and products. Danish (Beier et al. 1995) and Swedish (Linder. 1995; Nilsson. 1995) experiments have shown a large growth increase due to irrigation alone despite a relatively humid climate. Water also limits NPP and NEP in many low-latitude forest systems (Jain et al., 1989). Loss of forest systems and desertification is a global problem of growing significance (Sharma, 1992). Irrigation and other silvicultural techniques can be employed to stımulate NEP, but the economic costs of these practices and the lack of appropriate infrastructure make such efforts virtually impossible. Many tree species are well adapted to dry conditions, and reclamation of substandard soils and desertified sites is possible systems (Jain et al., 1989). Biomass production on these low-latitude sites can be 15-20/hectare. Given the large area of dryland natural forests, stimulation of $\mathrm{CO}_{2}$ production in these ecosystems is a globally significant opportunity (Dixon et al., 1994b).

\subsubsection{Select Useful Species and Genotypes}

The natural variation in NPP between provenances of the same tree species originating from a relatively small geographical area may be substantial,(e.g., Fife and Nambiar, 1995). Thus, selection of provenances well adapted to the site and expected climate may improve the NPP.

Tree improvement with some genera, including Pinus, Populus, Picea, Eucalyptus, Leucaena, Tectona, has dramatically improved the yield and other favourable commerical attributes over the last 50 years. However, it is not clear to what extent these increases in 
yield stem from increased NPP of individual trees, or simply reallocation of C from the noncommercial below-ground portions to stemwood.

A basic factor for improving NPP is a proper choice of tree species. Forest growth has declined in several locations responding to a poor choice of species (e.g. the decision to plant Picea abies on hardwood sites in central Europe). Because N limits NPP in many ecosystems, the introduction of such $\mathbb{N}$ fixing species like Alnus, at high latitudes, or Lueccaena, at low latitudes, would improve the nutrient status of the site, which would in turn improve (Jain et al., 1989). A large number of multipurpose tree species have been identified which can be employed to increase $\mathrm{C}$ sequestration and storage, or to improve site productivity on a sustained basis (Burley and Stewart, 1985).

Finally, enrichment planting below the main canopy can increase NEP in cases where one or more aspects of the growing sites are under utilized. This might occur in natural stands which are not fully stocked as a result of various non-stand-replacing disturbances. This technique could also be effective if shade tolerant species were planted below less tolerant ones. So, for example, mixed stands of Tsuga heterophylla and Pseudotsuga mensiesii have higher above-ground productivity than do pure stands of either species alone.

\subsubsection{Reduce Regeneration Delays}

Recovery of disturbed natural forests-whether by harvest, insect, fire, disease, blowdown, drought or any of a host of other factors--depends on both the availability of viable seed sources and suitability of site conditions. There is often a period of time-the regeneration delay-following disturbance where these criteria are not mer. On some sites, particularly low quality ones, losses of organic material and nutrient capital by leaching or erosion can both degrade the site potential and delay its realization. In some high quality sites, more successful opportunistıc species. such as grasses (e.g., Calamagrostis sp., in many northern systems) may invade the site and temporarily prevent the establishment of trees and the longer-term accumulation of phytomass. In both cases, such delays may be exacerbated by such factors as increased herbivory, and changes in soil structure or water table.

Appropriate choice of harvest timing and method can prevent regeneration delays. If regeneration is not prompt, such mitigation techniques as in-planting, site preparation, and nutrient supplements can be effective in speeding full stand occupancy with tree species (Winjum er al., 1993).

In extreme cases the site may fail to recover to its original forest cover and remain in a non-regenerated state (Dixon et al., 1994b). The C consequences are the same as ianduse changes. In less extreme cases, the regeneration delay introduces a corresponding delay in $\mathrm{C}$ accumulation.

\subsubsection{Select an Appropriate Harvest Method}

The current techniques for harvesting trees varies from the ancient practice of hand felling individual trees and yarding by gravity or draft animals to highly mechanized, capital intensive methods. The fossil $\mathrm{C}$ consumption per unit of $\mathrm{C}$ harvested is low even in the 
highly mechanized methods. Therefore, the fossil fuel use is not decisive in determining the impact of harvestıng method on $C$ sequestration.

Analogously to fires and pest outbreaks. logging methods can be divided into stand conserving and stand-replacing ones. Clearcutting is the most straight-forward technique for replacing a stand. However, sced-iree and shelterwood systems also remove most of the trees with a few left behind to provide the seeds and/or shelter for the new stand. Selective logging maintains forest cover while gradually replacing the stand. It can be used in some cases in a way that there never occurs a stand replacement phase: individual trees rather than the whole stand are replaced and rotated. Normally, trees are planted only in connection with stand-replacing harvest methods, but this practice is also appropriate as an enrichment technique as described above.

The choice of the harvesting method can have impacts on $\mathrm{C}$ sequestration, although such differences are poorly documented in literature. Olsson (1995) found that clear felling high-latitude forests resuits in significant losses of $\mathrm{C}$ and $\mathrm{N}$ from the humus layer down to $20 \mathrm{~cm}$ depth. Harvesting and the associated disturbance also influence $C$ pools and flux in low-latitude forests (Brown et al., 1991). Techniques which have been employed to conserve and sequester $\mathrm{C}$ in Malaysian forests inciude (i) preservation of non-harvested trees and associated vegetation by selective logging (versus clearcutting), (ii) before harvesting takes place, cutting vines which link boles of trees and thereby reducing the felling losses of non-target trees, and (iii) using low-impact harvesting systems which reduce soil disturbance (Dixon et al., 1993). The key to analyzing the impact is to measure and monitor the $\mathrm{C}$ pool in vegetation and soils over a fairly long period of time.

\subsubsection{Manage Logging Residues}

In some places, logging residues from forest management are, to a large extent, already being used as bioenergy (Sampson et al., 1993). In Finland and Sweden, bioenergy represents as much as $17-18 \%$ of all energy consumption when pulpmill residuals are included (Hall et al., 1993). Bioenergy substitutes directly for fossil fuels, in essence storing the $\mathrm{C}$ that would have been released in oil, gas or coal reserves.

Wholc-tree harvesting - where branches, needles and possibly root and stumps are removed-can increase the amount of the forest available for bioenergy. However, this treatment also reduces the pool of nutrients in the ecosystem, particularly in coniferous forests (Nilsson and Wiklund, 1994; 1995). On sites where nutrient availability limits NPP or NEP, this may result in reduced fixation of C (Olsson 1995). Fertilization can counteract this effect, but the carbon costs may not be favourable.

\subsubsection{Establish, Maintain and Manage Reserves}

Deforestation currently contributes about $2 / 7 \mathrm{~s}$ of all net $\mathrm{C}$ emissions (Dixon et al., 1994a; Houghton, et al., 1992). As a consequence, slowing the rate of deforestation will reduce $\mathrm{C}$ emissions as well as increasing the capacity of the globe to sequester $\mathrm{C}$. Two questions arise with this strategy: can suitable human intervention increase the stocks held in reserves? And what is the long-term fate of these stocks? Increases in the C stocks in rescrves can 
be accomplished by increasing the NEP of existing reserves or by sustaining or increasing the areal extent of such reserves.

At a stand-level, a set-aside forest reserve may accumulate $\mathrm{C}$ while in a growth phase, but as maturity is reached, growth decreases, respiration increases and net $C$ sequestration slows and may even decline as stand-breakup occurs. In many remperate and tropical forests, the forest stand may be maintained indefinitely in a closed canopy, mature state through some form of gap-phase replacement (Botkin 1992; Shugart, 1984; Leemans and Prentice, 1985). In the absence of stand-replacing disturbances, relatively smooth changes in $\mathrm{C}$ accumulation make take place in response to changes in nutrient or environmental conditions. In disturbance-regulated forests, such as the boreal forest, however, C stocks may rise and fall as large $\mathrm{C}$ pulses are associated with disturbance events. regeneration and the regrowth following it. As discussed previously, controlling these swings-particularly in isolated reserves-may be difficult.

The overriding point is this: $\mathrm{C}$ can retained by avoiding deforestation only if the $\mathrm{C}$ pools in the reserves are explicitly managed. Management of $\mathrm{C}$ pools may or may not be compatible with other desirable objectives for forest reserves such as preservation of biological diversity. Creation of a reserve might aiso simpiy displace the competing land users to a different location, with consequent impact on $\mathrm{C}$ stocks and sequestration rates. To compute the total impact of the reserve requires netting out these offsite effects.

\subsection{Economic Costs}

Most analysts agrec that it is most useful to describe the costs of $C$ sequestration in rerms of real monetary units (e.g., US\$ fixed at a specific date) per unit of $\mathrm{C}$ removed from the atmosphere (and perhaps per unit time). However, some confusion surrounds the exact way to measure this quantity, both for the numerator and for the denominator. Furthermore, most of the alternatives discussed above are continuous, in that to sequester more $\mathrm{C}$ the alternative can be more intensively applied (e.g., more fertilizer means higher growth rates; more protection means less $\mathrm{C}$ lost to fire). The optimal scale of the alternative must also be determined.

\subsubsection{Measuring Project Costs}

The economist's concept of cost for a specific activity refers to the value of the resources used if applied to their next best use. Where markets exist. market prices provide a useful guidepost of costs, so, for example, local wage rates measure the cost of labour used in a project and local machinery costs measure the costs of mechanized activities. In cases where markets are not well developed-either as a matter of government policy or as a matter of weak property or other institutions necessary for markets-the analyst must estimate the shadow prices of resource inputs in order to quantify the costs of $C$ sequestration.

Ideally the total cost of a project to sequester $\mathrm{C}$ should include both the direct costs of the project and the opportunity costs of resources used. A fail-safe approach to comprehensive cost analysis is the "with and without" approach. With this procedure the analyst 
determines the total economic return of an activity without the specific action rargeted to sequester $\mathrm{C}$, and then the total economic return of the action with the $\mathrm{C}$ sequestering activity inciuded. The cost of $\mathrm{C}$ sequestration is then the difference in the returns. For example, the cost of sequestering $\mathrm{C}$ by extending forest rotations is the difference in the net present values of the shorter and longer rotations, while accounting for all costs and benefits. That is, the costs of a $\mathrm{C}$ sequestration project should be the net costs. Any incremental benefits associated with the project not related to $\mathrm{C}$ sequestration should be subtracted from the project's direct costs. Examples include the recreation or aesthetic benefits of natural reserves, or the value of timber produced when management practices are intensified.

Because most natural forest management options extend across a long time period, the choice of discount rate will generally be quite consequential in determining the cost of $\mathrm{C}$ sequestration. Ideally the discount rate should reflect society"s preferences for consumption in one period compared with the next. One measure, albeit imperfect, is the real cost of long-term government debt. In fast-growing developing countries, the discount rate is logically higher than it is for more slowly growing developed countries. In the latter, discount rates of $2-4 \%$ are generally justifiable, while rates as high as $10 \%$ might be appropriate for the former. Because of the uncertainty surrounding the choice of discount rate - and its consequences for the analysis - good analytical practice always computes the present value of project costs for a range of values.

\subsubsection{Measuring $\subset$ Sequestration}

Most studies measure the amount of $\mathrm{C}$ sequestered as an average annual figure, and one of two approaches can be followed. In some cases, it will be possible to estimate the actual amount of $\mathrm{C}$ fixed each year (as, for example, bcing proportional to a conventional timber yield table). Alternatively, just as in the "with and without" analysis of economic costs, the amount of $\mathrm{C}$ fixed as the difference between stock of $\mathrm{C}$ without the activity and the stock with the activity divided by the number of years the project is in place.

These approaches assume that the present value of the damage of a unit of $C$ (the shadow price for $\mathrm{C}$ ) is the same regardless of when it is emitted. This assumption is unlikely to be true. Abatement, adaptation and mitigation technologies will change over time. Damages may be nonlinear in the total amount of $\mathrm{CO}_{2}$ in the atmosphere. All of these considerations suggest that, just as the economic costs of a $\mathrm{C}$ sequestration project must be discounted to determine their present value, the annual $\mathrm{C}$ emissions should be discounted (Richards, this volume; Richards and Stokes, 1995). Because of the complexities and ambiguities of this procedure, however, most analysis measure the costs of $\mathrm{C}$ sequestration as the present value of all costs (or their annualized equivalent) divided by the average annual amount of $\mathrm{C}$ sequestered over the project's life. Because this procedure docs not account for the temporal pattern of $\mathrm{C}$ releases, we suggest that the discounted sum of $\mathrm{C}$ flows (using the same discount ratc as for costs) should also be reported.

Finally, the extant iiterature focuses on ex ante forecasts of the amount of $\mathrm{C}$ which would be sequestered under various assumptions. As $\mathrm{C}$ sequestration policies are put in place, it will become necessary to measure the ex post quantities of $\mathrm{C}$ that actually are being sequestered. Such measurements will be required to monitor progress towards targets for 


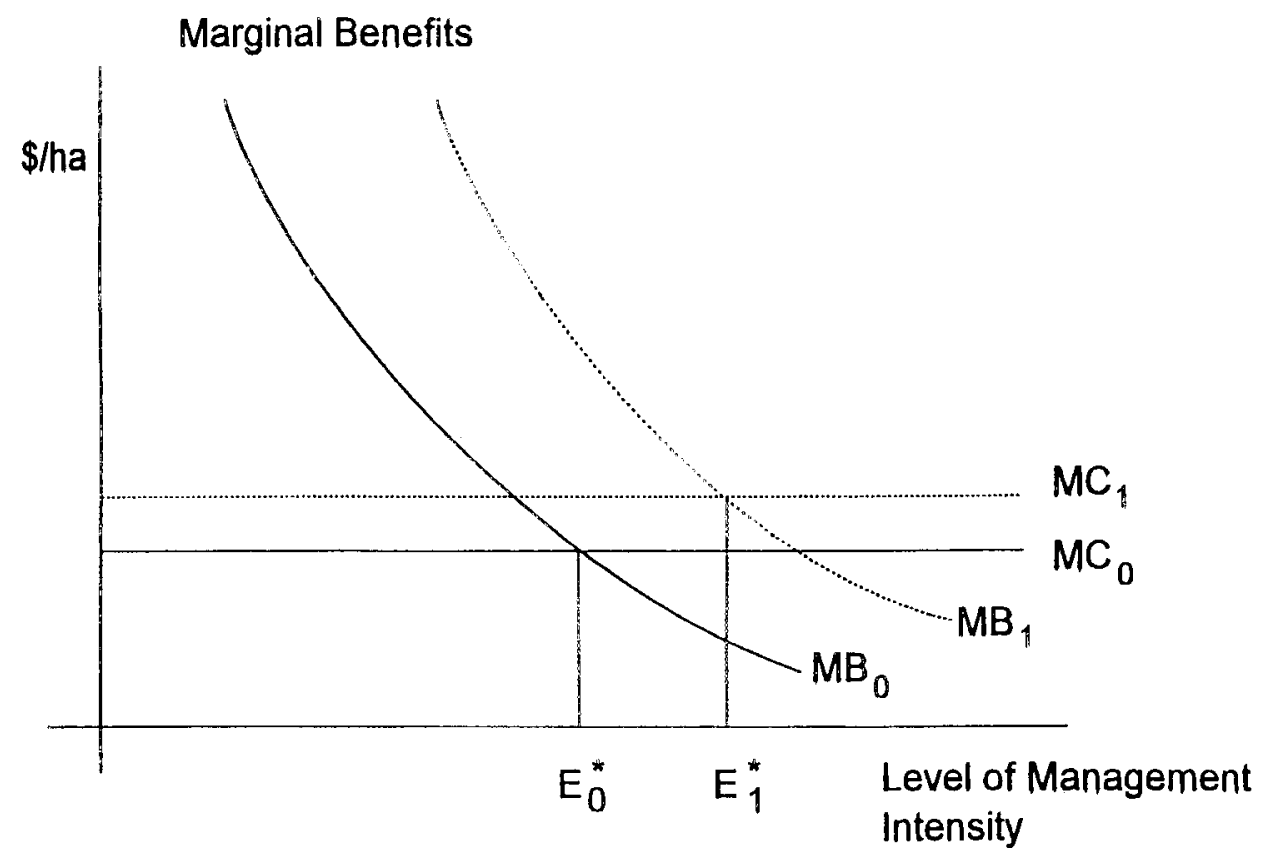

Protecting the Forest. Figure 1 shows the standard analysis of the optimal level of forest protection.

net emission reductions, and to verify any multiparty agreements about $\mathrm{C}$ offsets or "joint implementation projects". The level of precision needed for such measurements in natural forests currently exceeds that which ecosystem scientists can produce at a reasonable cost. We must either develop quick, inexpensive methods or be satisfied with indirect estimates from modeling procedures.

\subsubsection{Optimal Project Scale}

Because the biophysically fcasible management alternatives discussed above are ordinary forest management practices, considerable past analysis has centred on their optimal application. In many cases, these analytical methods can be extended in a straightforward way to incorporate the benefits of sequestering $\mathrm{C}$ and the cost of emitting it. To fix ideas, it is helpful to imagine that the $\mathrm{C}$ sequestration policy is implemented via a tax on $\mathrm{C}$ emissions and a subsidy for $\mathrm{C}$ sequestration, both levied on a per unit basis. The twelve alternatives discussed above fall into six general categories of economic concern.

Without considering the value of $\mathrm{C}$ sequestration, the optimal level occurs at $\mathrm{P}^{*} 0$ where the marginal cost of another unit of protection (perhaps measured as total forest area which is managed under a protection program) just equals the marginal benefits of avoided losses (e.g. the value of the timber and recreational values protected). Now consider the 
case where releasing $\mathrm{C}$ to the atmosphere carries a cost. Protection against fires, insects and diseases produces additional benefits equal to the upward shift from MV0 to MV1. The optimal level of protection increases to $\mathrm{P}^{*} 1$. Operationally this means that roads would be maintained further into the extensive margin of the forest. more people would be held on alert status during fire season, and so on. Finally, note that the marginal costs of protection might also rise in response both to a changed climate and to efforts to store more $C$ in the forests themselves. While the optimal level of protection is likely to increase, it will still probably not be economically efficient to exclude devastating fires or pest events from all forested areas, even if were physically possible and ecologically desirable to do so.

Fire monitoring and management in natural forest systems is the most efficient nearterm to conserve and sequester $\mathrm{C}$ in forest systems. Perhaps this point is best illustrated in boreal forest systems, where frequent occurrence of wildfire results in globally significant pulses of $\mathrm{CO}_{2}$ to the atmosphere (Dixon and Krankina 1992). Within the Russian Federat1on, forest fire monitoring systems (e.g., aircraft, satellites) in East or West Siberia or the Far East have not proven sufficiently efficient to support a fire management system. C emissions from wildfire, including direct and post-fire release are estimated to be approximately $0.2 \mathrm{Pg} \mathrm{C}$ annually. Improvement in forest fire monitoring and management systems and its expansion to all forest land in Russia can potentially reduce the are burned annually by $20 \%$ and thus conserve $0.05 \mathrm{Pg}$ C. Dixon and Krankina (1993) estimate that this C can be conserved in forest systems for much less than $\$ 1.00$ per hectare.

Rotation Length and the Optimal Amount of Growing Stock. Policies designed to sequester $\mathrm{C}$ in the forests themselves will logically increase the optimal forest rotation (van Kooten er al., 1995; Plantinga and Birdsey, 1995, Hoen and Solberg, 1994) and the optimal amount of growing stock in uneven-aged management systems. The logic of this is captured in the first-order condition for the optimal rotation in the presence of a C eternality (van Kooten. et al. 1995). In comparison with the usual Faustmann case, the presence of the $\mathrm{C}$ eternality creates an additional benefit of holding the stand longer because of the value of the $C$ sequestered. At the same time, the $C$ externally increases the costs of harvesting the stand because of the $\mathrm{C}$ emitted both from the ecosystem and from the industrial activities involved with processing the harvested timber. Both factors work to lengthen rotation ages, and the impact may be quite large (van Kooten et al., 1995). By similar logic, the optimal level of growing stock in a selection forest would increase in the presence of a $\mathbb{C}$ externally.

Stocking Control. Thinning performs three economic functions-harvesting trees that would otherwise succumb to suppression, accelerating the timing of cash flows from the stand, and increasing the piece size of the remaining trees. These benefits are purchased at the cost of a possible reduction in final harvest volumes. While the solution to the optimal thinning problem is quite complex, the presence of $\mathrm{C}$ externalities should generally favour repeated light thinnings, with some anticipated loss in final harvest volumes. The repeated light thinnings would harvest trees whose death and decay would contribute directly to $\mathrm{C}$ emissions. As long as the thinning were used for fossil fuel substitution or products with a longer life than that of the dead trees left to decay in the forest, their harvest would reduce or delay total $\mathrm{C}$ emissions. Thinnings heavy enough to reduce final harvest volume should lead to higher piecc sizes, and a larger fraction of the final harvest going into products with long useful lives. The tradeoff between the annual $\mathrm{C}$ reduction services of the unthinned 
stand and the higher amounts of $\mathrm{C}$ fixed when stand densities are lower must be computed for each specific case. Thinnings to waste should clearly be avoided (Hoen and Solberg, 1994), suggesting wider initial stockings than in situations where precommercial thinning is practiced.

Changes in Management Intensity. A number of management practices, including fertilization, and water control, are conceptually similar. The general problem of the

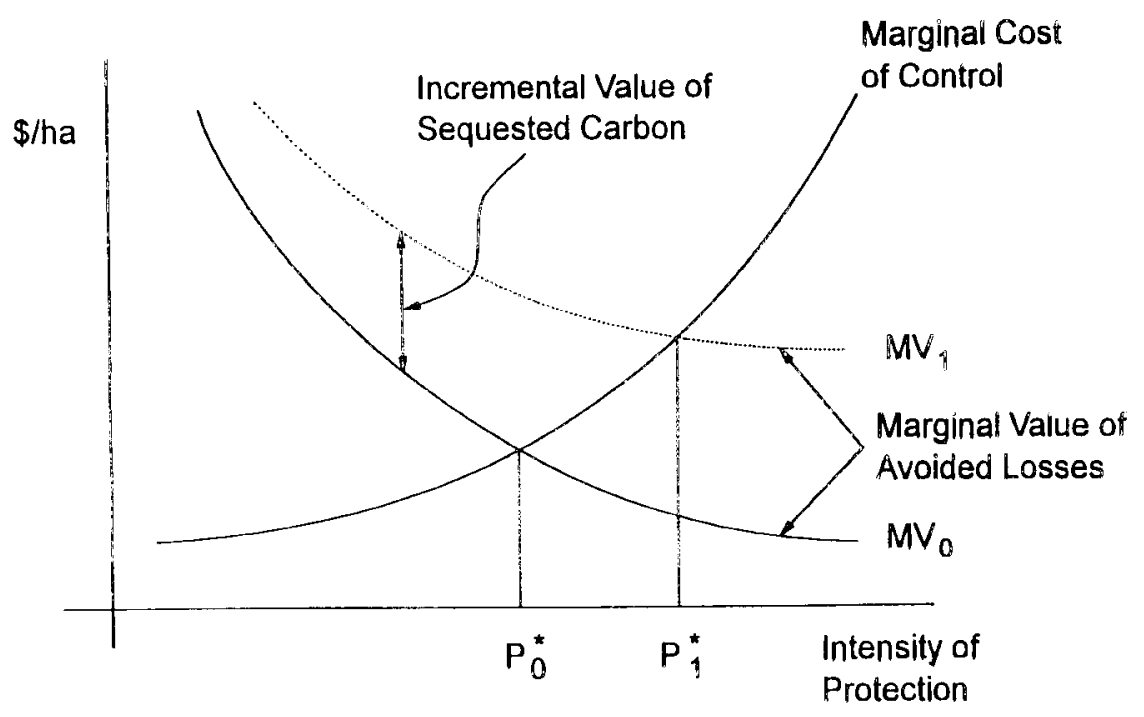

optimal level of management intensity is well understood (see, c.g., Hyde, 1980), and Figure 2 shows the general situation.

As with Figure 1, the subscripts 0 refer to the choice of management intensity in the absence of the $C$ externally. The optimal level occurs where the cost of another unit of management intensity $\mathrm{MCO}$ (e.g., the cost of a tonne of $\mathrm{N}$ fertilizer) just equals the marginal benefit of that unit of (e.g., the additional timber at the end of the rotation produced as a result of fertilization multiplied by the value of the timber). The $\mathrm{C}$ eternality will increase the marginal benefit of the management intensification, but may also increase the cost to the extent that $\mathrm{C}$ is released by the management intensification (e.g., in the production of fertilizers). The net effect is probably an increase in management intensity, although some specific circumstances might lead to the opposite result.

Utilization of Salvage and Logging Residues. The limit of utilization is defined by the smallest size and lowest quality of timber that just has enough value to "pay its way out of the woods." $\mathrm{C}$ sequestration policies will raise the value of small, low-quality logs either for fossil fuel offsets or as a store of $\mathrm{C}$ in the product sector. If such policies were implemented as a $\mathrm{C}$ tax on emissions and subsidy to sequestration, forest managers would utilize smaller stems rather than leave them as logging debris. 
Land-use. The margins of land use occur where the value of one use (e.g. for agriculture) just equals the value for another (e.g., forestry). $\mathrm{C}$ sequestration policies will increase the economic value of land-uses which store more $\mathrm{C}$ over those which store less. Hence the intensive margin should shift inward, with more land dedicated to forestry and less to agriculture and other uses. At the same time, the benefits of managing remote sites will increase, both through the value of products stored in the economic system via harvesting and the increased storage made possible by forest management. As a consequence, the extensive margin of utilization will shift outward. Masera (this volume) provides an interesting example of these effects in Mexico.

Deforestation is, in effect, an outward shift of the intensive margin of land-use, where a more intensive use such as agriculture displaces the less intensive forest use. In some cases, policies such as agricultural subsidies drive these changes. Policies targeted on sequestering $\mathrm{C}$ will work to offset these margin shifts, and help halt deforestation. In these circumstances it is logical also to examine how policies outside the forest sector are influencing such margin shifts.

\section{DISCUSSION AND CONCLUSIONS}

"Natural forests" comprise those lands currently occupied by closed forests or being regenerated to the same or similar species as removed from the site. The vast majority of the world's forest fall within this definition (perhaps over 95\%). They range from intensively managed natural forests of Central Europe and Scandinavia to the wild forests of the Russia and Canada and deep jungles of the tropics. Many indigenous people call these forests home. Much of the world's biological diversity is harboured within them.

There are numerous techniques for enhancing the capacity of these foresis to sequester C. While the literature provides useful analysis of some of these techniques (e.g. changes in rotation length, fertilization, stocking control, forest reserves), we have identified a somewhat longer list of possibilities which merit attention.

These are ordinary techniques of forest management already used to achieve other societal objectives. Viewed in this context, $\mathrm{CO}_{2}$ sequestration is but one of the multiple outputs of the forest. The $\mathrm{C}$ impact and cost of each of these techniques depends heavily on local conditions, perhaps even more so than is the case with afforestation and plantation management options because natural forest management begins by dealing with an existing growing stock. The literature suggests a range of costs for $\mathrm{C}$ sequestration in natural forests, from cheap to dear. Forest sector "joint implementation" projects, mostly established or sponsored by U.S. or European electric utilities, propose to conserve or sequester several $\mathrm{Tg}$ of $\mathrm{C}$ at initial project costs of less than $\$ 5.00$ per $\mathrm{Mg} \mathrm{C}$ (Dixon et al., 1993). Analysis of these projects reveals that the long-term costs of $\mathrm{CO}_{2}$ sequestration in natural forests are generally low or negative (e.g., yield net benefits).

Despite the fact that the biophysical responses will differ widely as one moves among the various tropical, temperate and boreal forests, a few general principles seem clear:

- Accumulating higher levels of growing stock is apt to increase the biophysical risk of holding stands managed expressly with $\mathrm{C}$ sequestration in mind,

- Because of poor access and their extensive nature, natural forest are already subject to a host of biotic and abiotic stresses, and climatic change will to add to these; 
- Increasing atmospheric concentrations of $\mathrm{CO}_{2}$ and climatic change will affect the amount of $\mathrm{C}$ stored in these forests;

- While it is possible in many cases to estimate ex ante the amount of $\mathrm{C}$ that will be sequestered under various management strategies, it will be extremely difficult to measure and verify these quantities in the field.

It is conceptually straightforward to determine the incremental cost of adding $\mathrm{C}$ sequestration as an objective of managing natural forests. Similarly, the literature contains many reports of attempts to compute the present value of these incremental costs of $\mathrm{C}$ sequestered on an average annual basis. However, the temporal pattern of $\mathrm{C}$ sequestration in natural forests will generally be complex, so all of the problems of "C discounting" will occur. As is the case with plantations, correct estimates of $\mathrm{C}$ sequestration will include that held in the economic system, both as fossil-fuel offsets and as long-lived products. While the economic concepts for measuring the net costs of $\mathrm{C}$ sequestration programs are clear, application of these concepts to specific cases may face daunting empirical obstacles related to the quality and availability of data, and the high cost of studies needed to estimate the value of such elusive benefits as the option value of preservation.

Weak physical and institutional infrastructure will impede implementing $C$ sequestration policies in many natural forests. In some places, traditional use of these forests by aboriginal people raises serious ethical questions about storing the offal from industrial society there. In other places, lack of physical access proscribes management intervention. Three general recommendations for policy attention seem appropriate:

- attend to how policies from other spheres of societal concern influence the capacity of natural forests to sequester C (c.g. agricultural subsidies encourage deforestation);

- look for opportunities to combine the solution of several problems into a single policy (e.g. use municipal waste water to fertilize forests);

- remember that the techniques for using natural forests to sequester $\mathrm{C}$ are quite traditional forest management practices. As a consequence, quite a lot is known about policy implementation, even if it is difficult.

Even in the absence of the problems associated with climatic change, the problems of poverty, weak political institutions, and expanding populations challenge our policies for the management of natural forests throughout the world. The new requirement for sequestering $\mathrm{C}$ and responding to altered climatic regimes in forests add to this burden. Given the relative complexity of forest-sector $\mathrm{C}$ offset projects, a number of biogeochemical, institutional and socioeconomic, monitoring and regulatory issues merit further analysis before the potential of this greenhouse gas stabilization approach can be fully understood.

\section{LITERATURE CITED}

Apps, M.J. and Kurz, W.A. (1993), The Role of Canadian Forests in the Global C Balance. In M. Kannien (Ed), C Balance on World's Forested Ecosystems: Towards a Global Assessment, Proc. Intergov. Panel on Climate Change Workshop, Joensuu, Finland, 11-15 May 1992, Publications of the Academy of Finland, Helsinki, 14-28. 
Auclair, A.N.D. and T. B. Carter (1993) Forest wildfires as a recent source of $\mathrm{CO}_{2}$ at nothern latitudes Canadian Journal of Foresi Research 23:1528-1536.

Beier, C., P. Gundersen, K. Hansen, and L. Rasmussen (1995), Experimental manipulation of water and nutrient input to a Norway spruce plantation at Klosterhede, Denmark. Il Effects on tree growth and nutrition. Plant and Soil 168-169: 613-622.

Berdén, M. (1994), Ion leaching and soil acidification in a forest Haplic Podzol: Effects of $\mathrm{N}$ application and clear-cutting. Doctoral Dissertation. Swedish University of Agricultural Sciences, Department of Ecology and Environmental Research, Rep 73. 21 pp. ISSN 0348-422x.

Botkin D.B., J.F. Janak, and J.R. Wallis (1972), Some ecological consequences of a computer model of forest growth. Journal of Ecology 60: 840-873.

Brown, S., C.A. Hall, W. Knabe, J. Raich, M.C. Trexler, and P. Woomer (1993), Tropical forests: their past, present and potential role in the terrestrial $\mathrm{C}$ budget. Water, Air and Soil Pollution 70:71-94.

Brown. S., J.R. Gillespie, and A.E. Lugo (199i), Biomass of tropical forests of south and southeast Asia. Canadian Journal of Forest Research 21:111-117

Burley, J. and J. Stewart (1985), Increasing productivity of multipurpose trees. International Union of Forest Research Organizations, Vienna, Austria.

Campinhos Jr. E. (1991), Plantation of fast-growing species for tropical areas. Actes du $10^{\circ}$ Congrès Forestier Mondial Vol. 5, Revue Forestière Française Hors Série No. 511-120.

Cofer III W.R., J.S. Levine, E.L. Winstead, and B.J. Stocks (1991), Chapter 27: Trace gas and particulate emissions from biomass burning in temperate ecosystems. in: Levine J.S. (Ed), Global biomass burning; atmospheric, climatic, and biospheric implications, MIT Press. Cambridge Mass., 203-208.

Cole, D.W. (1995), Soil nutrient supply in natural and managed forests. Plant and Soil 168-169: 4553.

Crutzen P.J., and J.G. Goldammer, eds. (1993). Fire in the environment: The ecological, atmospheric, and climatic tmporiance of vegetatton fires, John Wiley \& Sons, New York.

Davey, C.B. (1990), Forest fertilization in the americas. In: Nutrition of trees. The Marcus Wallenberg Foundation. Symposia proceedings:6. Lecures given at the 1989 Marcus Wallenberg Symposium in Falun, Sweden, on September 14, 1989. Strålins Tryckeri AB, Grycksbo. Sweden. ISSN 0282-4647. p.p. 33-56

Dixon R.K., and O.N. Krankina (1993), Forest fires in Russia: C dioxide emission to the atmosphere, Canadian Journal of Forest Research. 23:700-705.

Dixon, R.K, J.K. Winjum, K.J. Andrasko, J.J. Lce and P.E. Schroeder (1994b), Integrated land-use systems: Assessment of promising agroforest and alternative land-use practices to enhance $\mathrm{C}$ conservation and sequestration. Climatic Change 27:71-92.

Dixon, R.K. (1995), Silvicultural options to conserve and sequester C in forest systems: Preliminary economic assessment. this volume.

Dixon, R.K., J.K. Winjum and P.E. Schroeder (1993), Conservation and sequestration of C: The potential of forest and agroforest management practices. Global Environmental Change 2:159-173.

Dixon, R.K., K.J. Andrasko, F.G. Sussman, M.A. Lavinson, M.C. Trexler and T.S. Vinson (1993), Forest sector carbon offset projects: Near-term opportunities to mitigate greenhouse gas emissions. Water, Air and Soil Pollution 70:561-578.

Dixon, R.K., O.N. Krankina and K.I. Kobak (1995), Global climate change adaptation: anecdotes from Russian boreal forests. In Adaptation to Global Climate Change (J. Smith et al.,eds.) Springer-Verlag, Berlin, in press.

Dixon, R.K., S. Brown, R.A. Houghton, A.M. Solomon, M.C. Trexler, and J. Wisniewski (1994a), $\mathrm{C}$ pools and flux of global forest systems. Science 263:185-190.

Drake, B.G. (1992) The impact of rising $\mathrm{CO}_{2}$ on ecosystem production. Water, Air and Soil Pollution 64:25-44. 
Eriksson, H. and U.T. Joahnsson (1993), Yields of Norway spruce (Picea abies(l) Karst.) in two subsequent rotations in southwestern Sweden Plant and Soil 154:239-247.

Fife, D.N. and E.K.S. Nambiar (1995), Effect of $\mathrm{N}$ on growth and water relations of radiata pine families Plant and Soil 168-169:279-285.

Galinski W., J. Witowski (1995), Chapter 15: The C pulse resuiting from forest dieback related to insect outbreaks: Case study of a forest district in the Sudety Mountains (southwest Poland). in: Apps M.J. and Price D.T., eds. Forest Ecosystems. Forest Management and the Global C Cycle NATO ASI series, Springer-Verlag, Heidleberg, in press.

Hall, D.O., F. Rosillo-Calle, R.H. Williams, and J. Woods (1993), Biomass for Energy: Supply Prospects. In: B.J. Johansson. H. Kelly, A.K.N. Reddy \& R.H. Williams eds., Renewables for fuels and electricity. Island Press, Washington D.C.

Harmon, Franklin J.F., F.J. Swanson, P. Sollins, S.V. Gregory, J.D. Lattin, N.H. Anderson, S.P. Cline, N.G. Aumen, J.R. Sedeli, G.W. Lienkaemper, K. Cromack Jr., K.W. Cummins (1986), Ecology of coarse woody debris in temperate forest ecosystems. Advances in Ecological Research 15: 133-299

Harmon. M.E., W.K. Ferrell and J.F. Franklin (1990), Effects on C storage of conversion of oldgrowth forests to young forcsts. Science 247:699-702.

Hendrickson, O.Q. (1990), How does forestry influence atmospheric C? Forestry Chronicle 66:469472.

Henry, C.L., D.W. Cole, T.M. Hinckley, and R.B. Harrison (1994), The use of municipal and pulp and paper sludges to increase production in forestry. IUFRO Centennial Conference, Berlin, 1992

Houghton J.T., B.A. Callendar, and S.K.Varney (1992), Climate Change 1992. The Supplementary Report to the IPPCC Screntific Assessment. Cambridge University Press, Cambridge and New York.

Ingesiad. T. and G. Agren (1995), Plant nutrition and growth: Basical principles. Plant and Soil 168169: $15-20$.

Jain, R.K., K. Paliwal, R.K. Dixon, and D.H. Gjerstad (1989), Improving productivity of multipurpose trees growing on substandard soils. Journal of Forestry 87:38-40.

Johnsson, D.W. (1995). Effects of elevated $\mathrm{CO}_{2}$ and $\mathrm{N}$ on nutrient uptake in ponderosa pine seedlings. Plant and Soil 168-169: 535-545.

Kauppi, P., and M. Posch (1988), Chapter 5: A case study of the effects of $\mathrm{CO}_{2}$-induced climatic warming on forest growth and the forest sector: A. Productivity reactions of northern boreal forests. in: M.L. Parry, T.R. Carter, and N.T. Konijn, eds. The Impact of Climatic Variations on Agnculture. Kluwer Academic Publishers. p.p. 183-195.

Kauppi, P.E., E. Tomppo, and A. Ferm (1995), C and N storage in living trees within Finland since 1950s. Plant and Soil 168-169: 633-638.

King, G.A. (1993), Conceptual approaches for incorporating climate change into the development of forest management options for sequestering C. Climate Research 3:61-78.

Krankina, O.N. and R.K. Dixon (1992), Forest management in Russia: challenges and opportunities in the era of perestroika. Journal of Forestry 90:29-34.

Krankina, O.N. and R.K. Dixon (1994), Forest management options to conserve and sequester terrestrial C in the Russian Federation. World Resource Review 6:88-101.

Kurz WA, M.J. Apps, S.J. Beukema, and T. Lekstrum (1995), 20th century C budget of Canadian forests. Tellus 47B: 170-177.

Leemans R. and I.C. Prentice (1989), FORSKA: A general forest succession model. Meddelanden 2: 1-45. Växtbiologiska institutionen, Upsalla, Sweden.

Levine J.S., ed.. (1991), Global biomass burning; atmospheric, climatic, and biospheric implications, MIT Press, Cambridge Mass.

Marland G and S Marland (1992), Should we store C in trees?, Water, Air and Soil Pollution 64: 181195. 
Matthews R. (1995), Chapter 19: The influence of C budget methodology on assessments of the impacis of forest management on the $\mathrm{C}$ baiance. in: Apps M.J. and Price D.T., eds., Foresi Ecosystems, Forest Management and the Global C Cycle NATO ASI series, Springer-Verlag, Heidleberg, in press.

Matthews R., G.-J. Nabuurs, V. Alexeyev, R. Birdsey, A.Fischlin, J.P. Maclaren, J.P. Marland, and D.T. Price (1995), Chapter 24: Evaluating effects of alternative forest management regimes on the role of forests and forest products in the C cycle In: Apps M.J. and D.T. Price eds., Forest Ecosystems, Forest Management and the Global C Cycle NATO ASI series, Springer-Verlag, Heidleberg, in press.

Nambiar, E.K.S. and R. Sands (1993), Competition for water and nutrients in forests. Canadian Journal for Forestry Research 23:1955-1968.

Nilsson, L.O. and K. Wiklund (1992), Influence of nutrient and water stress on Norway spruce production in south Sweden-the role of air pollutants. Plant and Soil, 147: 251-265.

Nilsson, L.O. and K. Wiklund (1994), $\mathrm{N}$ accumulation in a Norway spruce stand following ammonium sulphate application, fertigation, irrigation, drought and nitogen-free-fertilisation. Plant and Soil 164:221-229.

Nilsson, L.O. and K. Wiklund (1995), Nutrient balance and P, K, Ca, Mg, S and B accumulation in a Norway spruce stand following ammonium sulphate application, fertigation, irrigation, drought and N-free-fertilisation. Plant and Soil 168-169: 437-446.

Niisson, L.O. (1995), Manipulation of conventional forest management practices to increase forest growth - results from the Swedish Skogaby project. Forest Ecology and Management (in press)

Olsson, B. (1995), Soil and vegetation changes after clear-felling coniferous forests: effects of varying removal of logging residues. Doctoral dissertation. Department of Ecology and Environmental Research, Swedish University of Agricultural Sciences. Report No. 80. ISSN $0348-422$ x. $25 \mathrm{pp}$

Sampson, R.N., L.L. Wright, J.K. Winjum, J.D. Kinsman, J. Benneman, B. Kursten, and J.M.O. Scurlock (1993), Biomass management and energy. Water, Air and Soil Pollution 70:139-162.

Schlamadinger B., and G. Marland (1995), Chapter 18: C implications of forest management strategies. In: Apps M.J. and Price D.T., eds. Forest Ecosystems, Forest Management and the Global C Cycle NATO ASI series, Springer-Verlag, Heidleberg, in press.

Sharma, N.P. ed., (1992), Managing the World's Forests. Kendall Hunt Publishing, Dubuque, IA, USA, 605p.

Schroeder, P.E. (1991), Can intensive management increase carbon storage in forests? Environmental Management 15:475-481.

Shugart H.H. (1984), A theory of forest dynamics: the ecological implications of forest succession models. Springer-Verlag, New York.

Smith, J.B. and D.A. Tirpak (1989), The potential effects of global climate change on the United States. EPA-230-05-89-050, U.S. EPA, Washington, DC, USA.

Smith, T.M., H.H. Shugart, G.B. Bonan and J.B. Smith (1991), Modeling the potential response of vegetation to global climate change. Advances in Ecological Research 22:93-116.

Stocks B.J. (1991), Chapter 26: The extent and impact of forest fires in northern circumpolar countries. In Levine J.S. (Ed), Global biomass burning; atmospheric, climatic, and biospheric implications, MIT Press, Cambridge Mass., 197-202.

Stocks, B.J. (1991), The extent and impact of forest fires in northern circumpolar countries. In J.S. Levine, ed., Global Biomass Burning: atmospheric, climatic and biospheric implications,. The MIT Press, Cambridge, MA, USA.

Tamm, C.O. (1991), N in terrestrial ecosystems. Questions of productivity, vegetational changes, and ecosystem stability. Ecological studies 81 . Springer-Verlag Berlin New York London. ISSN 3-540-51807x. 116 pp. 
Van Wagner C.E. (1978), Age-class distribution and the forest fire cycle. Canadian Journal of Forest Research 8: 2220-227.

Victor, D.G. and J.E. Salt (1995), Keeping the climate treaty relevant. Nature 373:280-282.

Volney W.J.A. (1995), Chapter 7: Climate change and management of insect defoliators in boreal forest ecosystems. in: M.J. Apps and D.T. Price eds. Forest Ecosystems, Forest Management and the Global C Cycle NATO ASI series, Springer-Verlag, Heidleberg, in press.

Weetman, G.F., H.H. Krause, E. Koller, and J.-M. Villeau (1987), "Interprovincial forest fertilization trials, 5 and 10 year results". Forestry Chronicle 63:184-192.

Winjum, J.K., R.K. Dixon, and P.E. Schroeder (1993), Forest management and carbon storage: an analysis of 12 key nations. Waier, Air and Soil Pollution 70:239-257.

Zolta1, S.C. and P.J. Martikainen (1985), Chapter 4: Estimated extent of forest peatlands and their role in the global C cycie. in: M.J. Apps and D.T. Price eds. Forest Ecosystems, Forest Management and the Global C Cycle NATO ASI series, Springer-Verlag, Heidleberg, in press. 